\title{
THE FORUM
}

\section{EDITORS}

David A. Hopkins, Boston University, USA

Jeffrey Stonecash, Syracuse University

\section{BOOK REVIEW EDITOR}

Rachel M Blum, Carl Albert Congressional Research and Studies Center and Department of Political Science at the University of Oklahoma

\section{EDITORIAL ASSISTANT}

Mercedes Wilby, The Graduate Center, City University of New York

\section{EDITORIAL BOARD}

Sarah A. Binder, George Washington University

Edward G. Carmines, Indiana University

James W. Ceaser, University of Virginia

Daniel DiSalvo, City College, City University of New York

Daniel Galvin, Northwestern University

D. Sunshine Hillygus, Duke University

Gary C. Jacobson, University of California, San Diego

Richard G. C. Johnston, University of British Columbia

Raymond J. La Raja, University of Massachusetts, Amherst

David R. Mayhew, Yale University

James Lee Ray, Vanderbilt University

Byron E. Shafer, University of Wisconsin, Madison

Peter N. Skerry, Boston College

Paul M. Sniderman, Stanford University

Laura Stoker, University of California, Berkeley

Amber Wichowsky, Marquette University

\section{DE GRUYTER}


This journal provides a forum for professionally informed commentary on issues affecting contemporary American politics. This includes but is not limited to issues engaging parties, elections, and political participation; the news media, interest groups, Congress, the Presidency, and the Courts; trends in public finance, presidential popularity, congressional productivity; in contemporary, historical, or comparative perspective.

The journal is motivated by the view that social scientists, historians, and legal scholars frequently have important insights into the concerns that arise in contemporary politics and government, drawing upon the disciplinary knowledge at their command. Yet they frequently lack a publishing outlet willing to print the analytic reasoning that gives weight to the resulting commentary. The Forum is designed to fill this gap.

We contemplate a journal free of fixed position and requiring no particular verdict with respect to policies, institutions, or processes. Well-reasoned discussion disciplined by reference to established bodies of knowledge or aimed at stimulating the creation of such knowledge is the goal of this journal.

ABSTRACTED/INDEXED IN Baidu Scholar · CNKI Scholar (China National Knowledge Infrastructure) · CNPIEC: cnpLINKer Dimensions EBSCO (relevant databases) - EBSCO Discovery Service · ERIH PLUS (European Reference Index for the Humanities and Social Sciences) - Genamics JournalSeek · Google Scholar · IBR (International Bibliography of Reviews of Scholarly Literature in the Humanities and Social Sciences) - IBZ (International Bibliography of Periodical Literature in the Humanities and Social Sciences) · J-Gate $\cdot$ Journal Citation Reports/Social Sciences Edition - JournalGuide · JournalTOCs · KESLI-NDSL (Korean National Discovery for Science Leaders) · Microsoft Academic · MyScienceWork · Naver Academic · Naviga (Softweco) · Primo Central (ExLibris) · ProQuest (relevant databases) · Publons · QOAM (Quality Open Access Market) - ReadCube - SCImago (SJR) · SCOPUS · Semantic Scholar · Sherpa/RoMEO · Summon (ProQuest) · TDNet . Ulrich`s Periodicals Directory/ulrichsweb · WanFang Data · Web of Science: Current Contents/Social and Behavioral Sciences; Social Sciences Citation Index · WorldCat (OCLC) · Yewno Discover

e-ISSN 1540-8884

All information regarding notes for contributors, subscriptions, Open Access, back volumes and orders is available online at http://www.degruyter.com/view/j/for.

EDITORIAL OfFICE David A. Hopkins, Associate Professor of Political Science, Boston College, 201 McGuinn Hall, 140 Commonwealth Ave, Chestnut Hill, MA 02467, (617) 552-6029, Email:david.hopkins@bc.edu

PUBLISHER Walter de Gruyter GmbH, Berlin/Boston, Genthiner Str. 13, 10785 Berlin, Germany

JOURNAL MANAGER Bettina Chang, De Gruyter, Genthiner Straße 13, 10785 Berlin, Germany, Tel.: +49 (0)30 260 05-356, Fax: +49 (0)30 260 05-250, Email: bettina.chang@ degruyter.com

RESPONSIBLE FOR ADVERTISEMENTS Markus Kügel, De Gruyter, Rosenheimer Str. 143, 81671 München, Germany, Tel.: +49 8976 902-424, e-mail: anzeigen@ degruyter.com

C 2021 Walter de Gruyter GmbH, Berlin/Boston

TYPESETTING TNQ Technologies, Chennai, India 


\section{Contents}

\section{Introduction}

Jeffrey Stonecash

Introduction Fall 2021 — 347

\section{Articles}

\section{Alan I. Abramowitz}

It's Only You and Me and We Just Disagree: The Ideological Foundations of Affective Polarization - 349

Trevor Brown, Suzanne Mettler and Samantha Puzzi

When Rural and Urban Become "Us" versus "Them": How a Growing Divide is Reshaping American Politics — 365

John R. Hibbing

Tribes and Proto-Tribes: The Deep Roots of Political Differences — 395

Steven W. Webster

The Role of Political Elites in Eliciting Mass-Level Political Anger — 415

Ian Reifowitz

The Legacy of Rush Limbaugh Will Always Be Tied to Donald Trump — 439

Alexa Bankert

Reflections on the Past and Present of Research on Partisan Identity - 459

Yphtach Lelkes

What Do We Mean by Negative Partisanship? - 481

David E. Campbell

Religion as Political Tribalism -499

Diana C. Mutz

The Tribal Economy: Economic Perceptions, Economic Anxiety and the Prospects for Political Accountability -519 


\section{Book Review}

Ivy A. M. Cargile

Racial Coalition Building in Local Elections: Elite Cues and Cross-Ethnic Voting - 543 